Weed Research, Japan

Vol. 36 (1) 27 35 (1991)

雑草研究

Report

\title{
Selective Mode of Action of Bensulfuron Methyl among Rice Cultivars*
}

\author{
Akira Ohno, Jong Yong Pyon**, Kozo Ishizuka, \\ and Hiroshi Matsumoto
}

\begin{abstract}
Effect of root-applied bensulfuron methyl \{3-(4,6-dimethoxypyrimidin-2-yl)-1[(2-methoxycarbonylbenzyl) sulfonyl] urea\} on growth of five rice cultivars (Oryza sativa L. cv. Milyang 30, Shingwang, Sangpung, Shinseonchalbyeo, and Nihonbare) was investigated under applied concentrations of $10^{-6}, 5 \times 10^{-6}$ and $10^{-5} \mathrm{M}$. Based on effects of the herbicide on growth of the plant parts (the 4th to 6th leaves and roots) which grew largely after its application, the order of sensitivity among tested cultivars to the herbicide is Nihonbare $>$ Sangpung, Shinseonchalbyeo $>$ Shingwag $\gg$ Milyang 30 . Root absorption of the ${ }^{14} \mathrm{C}$-herbicide and translocation from roots to shoots were investigated at $10^{-\mathrm{b}}$ and $10^{-\mathrm{b}} \mathrm{M}$ concentrations. There was no clear relation between the absorption or the translocation rates and the growth inhibition. Metabolism of root-absorbed ${ }^{14} \mathrm{C}$ bensulfuron methyl was studied in four of the cultivars, excluding Shinseonchalbyeo. Milyang 30 and Shingwang had lower percentages of the parent compound in roots than Sangpung and Nihonbare; they also had higher percentages of O-demethyl bensu-
\end{abstract}

Institute of Applied Biochemistry, University of Tsukuba, Tsukuba, Ibaraki 305, Japan

*This work was reported at the 26th annual meeting of the Weed Science Society of Japan in 1987 and at the 11 th conference of the Asian-Pacific Weed Science Society in 1987.

**Faculty of Agriculture, Chungnam National University, Daejeon 300-31, Korea

(Received April 15, 1988) lfuron methyl and water soluble metabolites than the latter two. In Milyang 30, bensulfuron methyl was less translocated from roots to shoots and largely degraded in roots, and these may contribute to its resistance. The low sensitivity of Shingwang may be related to its high degradation ability in roots, while in Nihonbare and Sangpung the rate of degradation of the herbicide was much lower than Milyang 30.

Key words: bensulfuron methyl, rice cultivar, absorption, translocation, metabolism

\section{Introduction}

Bensulfuron methyl \{3-(4,6-dimethoxypyrimidin-2-yl)-1- [(2-methoxycarbonylbenzyl)sulfonyl] urea\}, a sulfonylurea herbicide, selectively controls broadleaf weeds and sedges in paddy rice field. This compound is active at an extremely low dosage of $20-50 \mathrm{~g}$ ai/ $\mathrm{ha}^{9}$.

The mode of action of sulfonylurea herbicides has been studied intensively by $\mathrm{Ray}^{7}$. The reduction in growth by chlorsulfuron, one of the sulfonylurea herbicides, was closely associated with an inhibition of plant cell division. Under conditions where cell division occurred, DNA synthesis was strongly inhibited. Since that finding, the primary site of these compounds has been considered to be an inhibition of acetolactate synthase, a key enzyme for branched-chain amino acid biosynthesis ${ }^{8}$. Bensulfuron methyl inhibits acetolactate synthase from weeds associated 
with rice cultivation ${ }^{10)}$, and this inhibition may account for the herbicidal action of the chemical.

The difference in sensitivity among rice cultivars has been reported for simetryn ${ }^{1 \sim 3)}$, benthiocarb $^{1)}$, and other herbicides ${ }^{4)}$. In field tests in Thailand and Japan, japonica type rice cultivars were generally more sensitive to bensulfuron methyl than indica type cultivars ${ }^{11)}$. Ohno et $a l .{ }^{6)}$ reported that japonica type rice cultivars were often more susceptible than indica type cultivars or hybrids of japonica and indica. Nakayama et al. ${ }^{5)}$ also reported on susceptibility differences to bensulfuron methyl. The mechanism of rice cultivar differential sensitivity to this herbicide, however, has not been investigated.

In this study, we were interested in the selective mode of action of bensulfuron methyl in Korean rice cultivars and japonica rice cultivar $\lceil$ Nihonbare $\rfloor$. The Korean cultivars used were selected from among many Korean types against bensulfuron methyl. First, we attempted to determine differential sensitivity of the cultivars to root applied bensulfuron methyl in a water culture. Interactions between the herbicide and rice plants were then examined from the aspects of root absorption, and the translocation and metabolism of the herbicide in the plants.

\section{Materials and Methods}

\section{Plants}

To compare the tolerance of rice (Oryza sativa L.) cultivars to bensulfuron methyl, five cultivars, Milyang 30, Shingwang. Sangpong, Shinseonchalbyeo, and Nihonbare were selected through a preliminary experiment. The former two were hybrids of japonica and indica and the latter three were japonica types.

Rice seeds were germinated in darkness for 2 days at $25^{\circ} \mathrm{C}$ in an incubator. Uniform seedlings were selected and transferred to plastic trays. The plants were grown in Kasugai nutrient solution until the 3rd leaf stage in a growth chanmber at $25^{\circ} \mathrm{C}$ daytime and $20^{\circ} \mathrm{C}$ during the night, at $55-60 \%$ relative humidity with 12 hours daylength and light intenstiy of $15 \mathrm{klx}$.

\section{Root application of bensulfuron methyl}

Roots of intact seedlings at the 3rd leaf stage were soaked in Kasugai nutrient solution containing $10^{-5}, 5 \times 10^{-6}$, or $10^{-6} \mathrm{M}$ of bensulfuron methyl for 4 days. The roots were washed with distilled water and then transferred to bensulfuron methyl-free Kasugai nutrient solution and grown another 6 days in a growth chamber. At harvest, plant height, leaf length and dry weight of roots and shoots were measured. The treatment was replicated 3 times using 3 plants for each replication.

\section{Absorption and translocation of bensul- furon methyl}

Uniformly ${ }^{14} \mathrm{C}$-labeled bensulfuron methyl at phenyl ring with a specific activity of 5.6 $\times 10^{5} \mathrm{~Bq} / \mathrm{mg}$ was used in the study. Roots of intact seedlings were soaked in $0.5 l$ of $10^{-6}$ or $10^{-5} \mathrm{M}{ }^{14} \mathrm{C}$-bensulfuron methyl for $3,6,24$, and 48 hours and thereafter were removed and blotted dry. They were then sectioned into shoots and roots, oven dried at $90^{\circ} \mathrm{C}$ for 24 hours, weighed and combusted in an automatic sample combustion system (Aloka AS C-113) ; radioactivity was determined by a liquid scintillation spectrophotometer (LSS, Beckman LS-1801). Translocation rate was calculated by rate of radioactivity in shoots to that in whole plants. The treatment was replicated 3 times using 2 plants each.

\section{Metabolism of bensulfuron methyl}

Roots of intact seedlings were soaked in $0.8 l$ of $1 \times 10^{-6} \mathrm{M}^{14} \mathrm{C}$-bensulfuron methyl for 6 or 24 hours. Following the absorption period the plants were removed from the solution, roots rinsed with distilled water and the plants sectioned into shoots and roots. Each treatment was duplicated using 30 plants. After determination of their fresh weight, each plant part was separately homogenized and extracted twice with $80 \%$ acetone. The 
radioactivity of the combined extracts and nonextractable residues was determined and then acetone in the extracts was evaporated in vacuo at $35^{\circ} \mathrm{C}$. Aqueous residue was adjusted to $\mathrm{pH} 7$ with ammonium hydroxide and partitioned with dichloromethane. Then the aqueous residue was adjusted to $\mathrm{pH} 3$ with phosphoric acid and partitioned again with dichloromethane. The radioactivities in dichloromethane extracts at $\mathrm{pH} 7$ and $\mathrm{pH} 3$, and water fractions were determined by LSS. Radioactive compounds in dichloromethane at pH 7 and pH 3 were analyzed by thin-layer chromatography (TLC). For TLC analysis, aliquots of each concentrate were applied as a band to silica gel (Merck Silica gel $60 \mathrm{~F}$ 354 , layer thickness of $250 \mu \mathrm{m}$ ) and Sic18 (Whatman $\mathrm{KC18F}$, layer thickness of $200 \mu$ $\mathrm{m})$ plates. The plates were developed with a mixture of dichloromethane/methanol $/ \mathrm{NH}_{4}$
$\mathrm{OH}(144 / 50 / 6, \mathrm{v} / \mathrm{v} / \mathrm{v}$ : for silica gel plate), or with a mixture of dichloromethane/acetonitrile/glacial acetic acid/water (150/27/2.5/ $0.3, \mathrm{v} / \mathrm{v} / \mathrm{v} / \mathrm{v}$ : for Sic18 plate). Authentic reference standards of expected plant metabolites were co-chromatographed. The nonradiolabeled standards were detected under a UV monitor. Radiolabeled compounds in TLC plates were detected by Fuji X-ray film and their bands of radioactivity were counted quantitaively by LSS.

\section{Results}

\section{Growth response of rice cultivars to bensulfuron methyl}

Effect of root applied bensulfuron methyl to growth of the rice plants was evaluated by lengths of the 4 th, 5 th and 6 th leaves, and the dry weights of roots and shoots(Table 1). Degrees of growth inhibition were shown as

Table 1. Growth of 5 rice cultivars as affected by bensulfuron methyl (BSM) treatment under solution culture condition.

\begin{tabular}{|c|c|c|c|c|c|c|c|c|c|c|c|}
\hline \multirow{2}{*}{$\begin{array}{l}\text { Rice } \\
\text { cultivar }\end{array}$} & \multirow{2}{*}{$\begin{array}{l}\text { BSM } \\
\text { conc.(M) }\end{array}$} & \multicolumn{6}{|c|}{ Leaf length } & \multicolumn{4}{|c|}{ Dry weight (per 3 plants) } \\
\hline & & 4 th & $(\%)$ & \multicolumn{2}{|c|}{5 th } & \multicolumn{2}{|c|}{6 th } & \multicolumn{2}{|c|}{ Shoot } & Root & t $(\%)$ \\
\hline $\begin{array}{l}\text { Milyang } \\
30\end{array}$ & $\begin{array}{r}0 \\
10^{-6} \\
5 \times 10^{-6} \\
10^{-5}\end{array}$ & $\begin{array}{l}9.7^{\mathrm{a}} \\
9.1^{\mathrm{ab}} \\
8.5^{\mathrm{bc}} \\
8.1^{\mathrm{c}}\end{array}$ & $\begin{array}{r}100 \\
94 \\
88 \\
84\end{array}$ & $\begin{array}{r}12.7^{\mathrm{a}} \\
10.3^{\mathrm{b}} \\
8.0^{\mathrm{c}} \\
8.0^{\mathrm{c}}\end{array}$ & $\begin{array}{r}100 \\
81 \\
63 \\
63\end{array}$ & $\begin{array}{l}5.3^{\mathrm{a}} \\
2.4^{\mathrm{b}} \\
2.1^{\mathrm{b}} \\
0.9^{\mathrm{c}}\end{array}$ & $\begin{array}{r}100 \\
45 \\
40 \\
17\end{array}$ & $\begin{array}{l}0.185^{\mathrm{a}} \\
0.148^{\mathrm{b}} \\
0.124^{\mathrm{c}} \\
0.122^{\mathrm{c}}\end{array}$ & $\begin{array}{r}100 \\
80 \\
67 \\
66\end{array}$ & $\begin{array}{l}0.070^{\mathrm{a}} \\
0.059^{\mathrm{b}} \\
0.045^{\mathrm{c}} \\
0.048^{\mathrm{c}}\end{array}$ & $\begin{array}{r}100 \\
84 \\
64 \\
69\end{array}$ \\
\hline $\begin{array}{l}\text { Shing- } \\
\text { wang }\end{array}$ & $\begin{array}{r}0 \\
10^{-6} \\
5 \times 10^{-6} \\
10^{-5}\end{array}$ & $\begin{array}{l}13.1^{\mathrm{a}} \\
11.6^{\mathrm{b}} \\
11.4^{\mathrm{b}} \\
10.6^{\mathrm{b}}\end{array}$ & $\begin{array}{r}100 \\
89 \\
87 \\
81\end{array}$ & $\begin{array}{c}16.0^{\mathrm{a}} \\
9.1^{\mathrm{b}} \\
8.9^{\mathrm{b}} \\
5.5^{\mathrm{b}}\end{array}$ & $\begin{array}{r}100 \\
57 \\
56 \\
34\end{array}$ & $\begin{array}{r}2.5^{\mathrm{a}} \\
0^{\mathrm{b}} \\
0^{\mathrm{b}} \\
0^{\mathrm{b}}\end{array}$ & $\begin{array}{r}100 \\
0 \\
0 \\
0\end{array}$ & $\begin{array}{l}0.180^{\mathrm{a}} \\
0.120^{\mathrm{b}} \\
0.121^{\mathrm{b}} \\
0.110^{\mathrm{b}}\end{array}$ & $\begin{array}{r}100 \\
67 \\
67 \\
61\end{array}$ & $\begin{array}{l}0.055^{\mathrm{a}} \\
0.041^{\mathrm{b}} \\
0.036^{\mathrm{c}} \\
0.031^{\mathrm{c}}\end{array}$ & $\begin{array}{r}100 \\
75 \\
65 \\
56\end{array}$ \\
\hline $\begin{array}{l}\text { Sang- } \\
\text { pung }\end{array}$ & $\begin{array}{r}0 \\
10^{-6} \\
5 \times 10^{-6} \\
10^{-5}\end{array}$ & $\begin{array}{l}17.6^{\mathrm{a}} \\
14.9^{\mathrm{b}} \\
13.3^{\mathrm{c}} \\
13.4^{\mathrm{c}}\end{array}$ & $\begin{array}{r}100 \\
85 \\
76 \\
76\end{array}$ & $\begin{array}{c}20.3^{\mathrm{a}} \\
10.7^{\mathrm{b}} \\
7.3^{\mathrm{c}} \\
2.4^{\mathrm{d}}\end{array}$ & $\begin{array}{r}100 \\
53 \\
36 \\
12\end{array}$ & $\begin{array}{r}1.9^{\mathrm{a}} \\
0^{\mathrm{b}} \\
0^{\mathrm{b}} \\
0^{\mathrm{b}}\end{array}$ & $\begin{array}{r}100 \\
0 \\
0 \\
0\end{array}$ & $\begin{array}{l}0.214^{\mathrm{a}} \\
0.147^{\mathrm{b}} \\
0.143^{\mathrm{b}} \\
0.145^{\mathrm{b}}\end{array}$ & $\begin{array}{r}100 \\
69 \\
65 \\
68\end{array}$ & $\begin{array}{l}0.077^{\mathrm{a}} \\
0.049^{\mathrm{b}} \\
0.036^{\mathrm{c}} \\
0.037^{\mathrm{c}}\end{array}$ & $\begin{array}{r}100 \\
64 \\
47 \\
48\end{array}$ \\
\hline $\begin{array}{l}\text { Shin- } \\
\text { seonchal- } \\
\text { byeo }\end{array}$ & $\begin{array}{r}0 \\
10^{-6} \\
5 \times 10^{-6} \\
10^{-5}\end{array}$ & $\begin{array}{l}18.7^{\mathrm{a}} \\
16.8^{\mathrm{b}} \\
15.4^{\mathrm{c}} \\
14.9^{\mathrm{c}}\end{array}$ & $\begin{array}{r}100 \\
90 \\
82 \\
80\end{array}$ & $\begin{array}{r}18.5^{\mathrm{a}} \\
11.2^{\mathrm{b}} \\
7.2^{\mathrm{c}} \\
5.2^{\mathrm{d}}\end{array}$ & $\begin{array}{r}100 \\
61 \\
39 \\
28\end{array}$ & $\begin{array}{r}5.3^{\mathrm{a}} \\
0^{\mathrm{b}} \\
0^{\mathrm{b}} \\
0^{\mathrm{b}}\end{array}$ & $\begin{array}{r}100 \\
0 \\
0 \\
0\end{array}$ & $\begin{array}{l}0.230^{\mathrm{a}} \\
0.166^{\mathrm{bc}} \\
0.158^{\mathrm{cd}} \\
0.143^{\mathrm{d}}\end{array}$ & $\begin{array}{r}100 \\
72 \\
69 \\
62\end{array}$ & $\begin{array}{l}0.073^{\mathrm{a}} \\
0.044^{\mathrm{b}} \\
0.034^{\mathrm{c}} \\
0.030^{\mathrm{c}}\end{array}$ & $\begin{array}{r}100 \\
60 \\
47 \\
41\end{array}$ \\
\hline $\begin{array}{l}\text { Nihon- } \\
\text { bare }\end{array}$ & $\begin{array}{r}0 \\
10^{-6} \\
5 \times 10^{-6} \\
10^{-5}\end{array}$ & $\begin{array}{l}18.5^{\mathrm{a}} \\
15.6^{\mathrm{ab}} \\
13.8^{\mathrm{bc}} \\
11.6^{\mathrm{c}}\end{array}$ & $\begin{array}{r}100 \\
84 \\
75 \\
63\end{array}$ & $\begin{array}{r}20.5^{\mathrm{a}} \\
7.4^{\mathrm{b}} \\
1.4^{\mathrm{c}} \\
0^{\mathrm{d}}\end{array}$ & $\begin{array}{r}100 \\
36 \\
7 \\
0\end{array}$ & $\begin{array}{r}3.6^{\mathrm{a}} \\
0^{\mathrm{b}} \\
0^{\mathrm{b}} \\
0^{\mathrm{c}}\end{array}$ & $\begin{array}{r}100 \\
0 \\
0 \\
0\end{array}$ & $\begin{array}{l}0.246^{\mathrm{a}} \\
0.159^{\mathrm{b}} \\
0.159^{\mathrm{b}} \\
0.144^{\mathrm{b}}\end{array}$ & $\begin{array}{r}100 \\
65 \\
65 \\
59\end{array}$ & $\begin{array}{l}0.079^{\mathrm{a}} \\
0.047^{\mathrm{b}} \\
0.040^{\mathrm{c}} \\
0.032^{\mathrm{d}}\end{array}$ & $\begin{array}{r}100 \\
59 \\
51 \\
41\end{array}$ \\
\hline
\end{tabular}

Means followed by the same alphabets in columns of each cultivar are not significantly different at $5 \%$ level by Duncan's multiple range test.

Percentage indicates ratio of determined value of herbicide treated plants to determined value of nontreated plants in each rice cultivar. 
a percent of control.

The effect of bensulfuron methyl was investigated on each leaf. At the treatment with the herbicide, the 4th leaf had emerged a little. In the $10^{-6} \mathrm{M}$ treatment, Milyang 30 had only slight 4 th leaf damage, while other cultivars tested sustained $10 \sim 15 \%$ growth retardation. In the $5 \times 10^{-6} \mathrm{M}$ treatment, the growth inhibition of Sangpung and Nihonbare was about $25 \%$, greater than the other 3 cultivars. In the $10^{-5} \mathrm{M}$ treatment, the rate of inhibition of Nihonbare was $40 \%$, and damage to other cultivars was nearly the same as in the $5 \times 10^{-6} \mathrm{M}$ treatment. In the 5 th leaf length, Milyang 30 showed the least inhibition among all cultivars: $19 \%$ in the $10^{-6} \mathrm{M}$ treatment. The 5 th leaf of Nihonbare was injured the most with a rate of inhibition of $64 \%$ in the $10^{-6} \mathrm{M}$ treatment. In $5 \times$ $10^{-6} \mathrm{M}$, the inhibition degree of Nihonbare was a remarkably large $93 \%$, while, in contrast, Milyang 30 growth was only slightly inhibited by the same treatment; even in the $10^{-5} \mathrm{M}$ treatment, the rate of inhibition of Milyang 30 was $47 \%$. Strong inhibition occurred in Sangpung and Shinseonchalbyeo at treatments of $5 \times 10^{-6} \mathrm{M}$ and $10^{-5} \mathrm{M}$, and the 5 th leaf of Nihonbare did not emerge at all with the $10^{-5} \mathrm{M}$ treatment. Milyang 30 was the only cultivar among the rice plants treated of which the 6 th leaf emerged.

For the effect on dry weight of shoots; the only cultivar suffering slight damage by $10^{-6}$ $\mathrm{M}$ bensulfuron methyl was Milyang 30 , others had remarkable damage. In the $5 \times 10^{-6}$ $M$ treatment, degrees of inhibition ranged from 31 to 35 in all cultivars. In the $10^{-5} \mathrm{M}$ treatment, Milyang 30 and Sangpung were less damaged than the other 3 cultivars.

For the effect on dry weight of roots, inhibition degree of Milyang 30 was again the least of all cultivars in the $10^{-6} \mathrm{M}$ treatment followed by Shingwang. In the $5 \times 10^{-6} \mathrm{M}$ treatment, rates of growth inhibition of Milyang 30 and Shingwang were about $40 \%$ but other cultivars were inhibited about $50 \%$. In the $10^{-5} \mathrm{M}$ treatment. Milyang 30 was inhibited the least, to a degree about the same level as in the $5 \times 10^{-6} \mathrm{M}$ treatment. Shingwang was inhibited more strongly in the $10^{-5} \mathrm{M}$ treatment than in $5 \times 10^{-6} \mathrm{M}$, but its degree of inhibition was still less than other
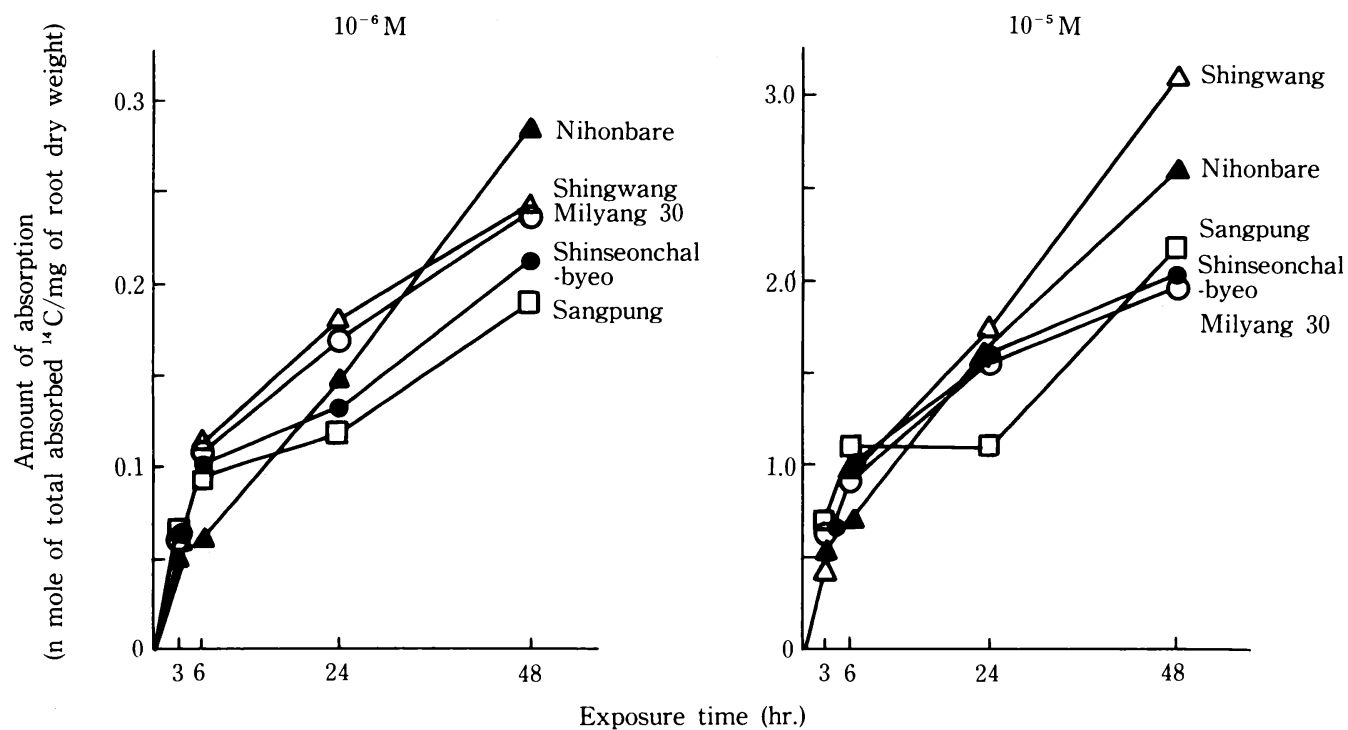

Fig. 1. Absorption of ${ }^{14} \mathrm{C}$-bensulfuron methyl by roots of rice cultivars at the 3rd leaf stage. 
cultivars except Milyang 30.

2. Absorption and translocation of ${ }^{14} \mathrm{C}$ bensulfuron methyl

Absorption of ${ }^{14} \mathrm{C}$-bensulfuron methyl by roots and translocation to shoots were studied with 2 concentrations, $10^{-6} \mathrm{M}$ and $10^{-5} \mathrm{M}$.

\section{2-1 Absorption}

Figure 1 shows results of the absorption experiment as absorption values which were obtained by dividing the absorbed amount of ${ }^{14} \mathrm{C}$-radioactivity in plants by dry weight of roots, the organs of absorption.

With $10^{-6} \mathrm{M}$, no great difference in absorption among the 5 rice cultivars was noted at 3 hours, and at 6 hours Nihonbare had a less absorption value than other cultivars. At 24 hours, the absorption values of Shingwang and Milyang 30 were larger than the other 3 cultivars. At 48 hours, Nihonbare showed the largest absorption value among all cultivars, with Shingwang and Milyang 30 next.

With $10^{-5} \mathrm{M}$, there was no great difference in absorption value among the 5 cultivars. That of Nihonbare was less than the others at 6 hours and Sangpung was less than the others at 24 hours. At 48 hours, Shingwang showed the largest absorption value among

$$
10^{-6} \mathrm{M}
$$
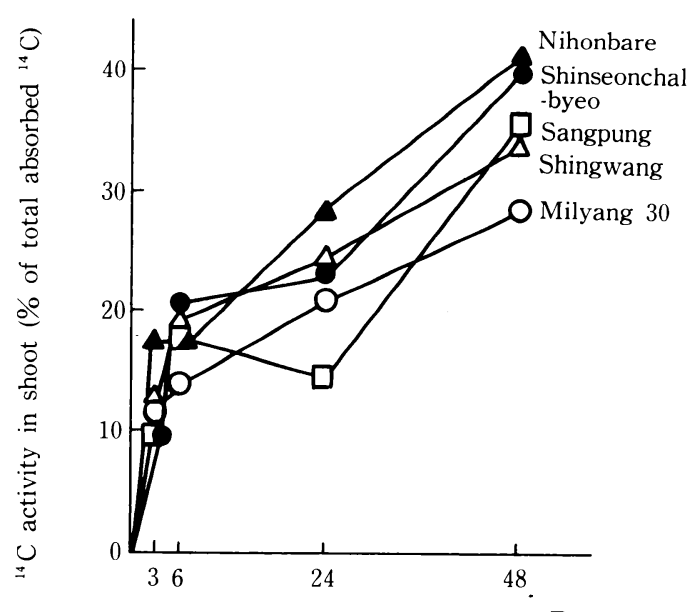

Exposure time (hr.)

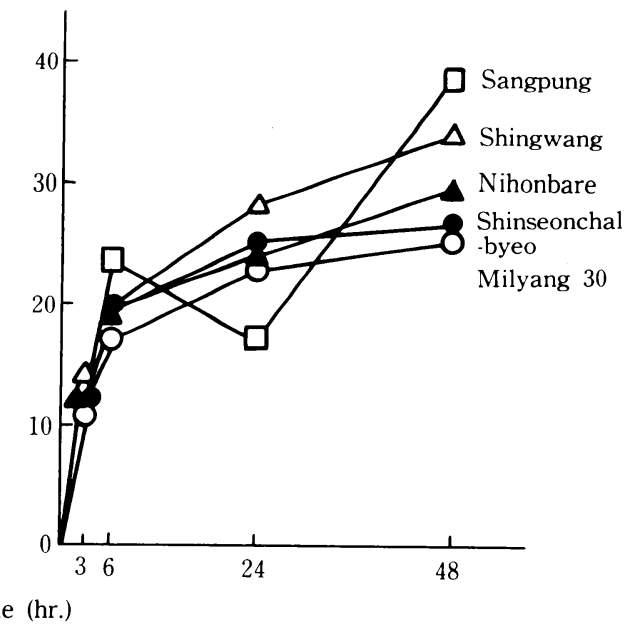

Fig. 2. Rate of translocation from roots to shoots of ${ }^{14} \mathrm{C}$-bensulfuron methyl in rice cultivars at the 3rd leaf stage. 
increased and reached about $40 \%$; Shingwang showed the next highest and the rate of Nihonbare was about $30 \%$. The rates of Shinseonchalbyeo and Milyang 30 did not greatly increase.

\section{Metabolism of ${ }^{14} \mathrm{C}$-bensulfuron} methyl

Degradation of ${ }^{14} \mathrm{C}$-bensulfuron methyl in rice plants was studied, in an experiment in which $10^{-6} \mathrm{M}$ of the herbicide was absorbed by roots for either 6 or 24 hours.

Figure 3 shows percents of ${ }^{14} \mathrm{C}$-compounds which presented in roots and shoots after 6 hours. More than $90 \%$ of ${ }^{14} \mathrm{C}$-compounds were detected in root parts of all cultivars. The amount of non-degraded parent compound in roots was about $45 \%$ in Milyang 30 and Shingwang, while in Sangpung and $\mathrm{Ni}$ honbare it was more than $55 \%$. The metabolic product found in the largest amount in roots was sulfonamide; there was no great difference detected among all cultivars, with the percents of $23 \sim 27 \%$. The total amount of O-demethyl bensulfuron methyl, an unidentified compound and metabolites in the water soluble fraction in Milyang 30 and
Shingwang were larger than in Sangpung and Nihonbare.

At the 24 hour exposure, percents of ${ }^{14} \mathrm{C}$ compounds detected in shoots were $19 \%, 26$ $\%, 29 \%$ and $29 \%$ in Milyang 30, Shingwang, Sangpung and Nihonbare, respectively (Fig.4). Percents of parent compound in roots were $29 \%$ and $26 \%$ in Milyang 30 and Shingwang, respectively, and less than the about 35\% in Sangpung and Nihonbare. Percent of sulfonamide was around $19 \%$ in each cultivar. Percents of O-demethyl bensulfuron methyl and metabolites in the water soluble fraction in roots were larger in Milyang 30 and Shingwang than in Sangpung and Nihonbare. Percent of non-extracted ${ }^{14} \mathrm{C}$-radioactivity was larger in Milyang 30 than in other cultivars. At 24 hours, rate of the parent compound in shoots was less that in roots in all cultivars. The greatest radioactivity in metabolites was found as sulfonamide, similar to the finding in roots. Percent of sulfonamide in Milyang 30 was larger than in other cultivars. Percents of O-demethyl bensulfuron methyl and metabolites of the water soluble fraction in Sangpung and Nihonbare

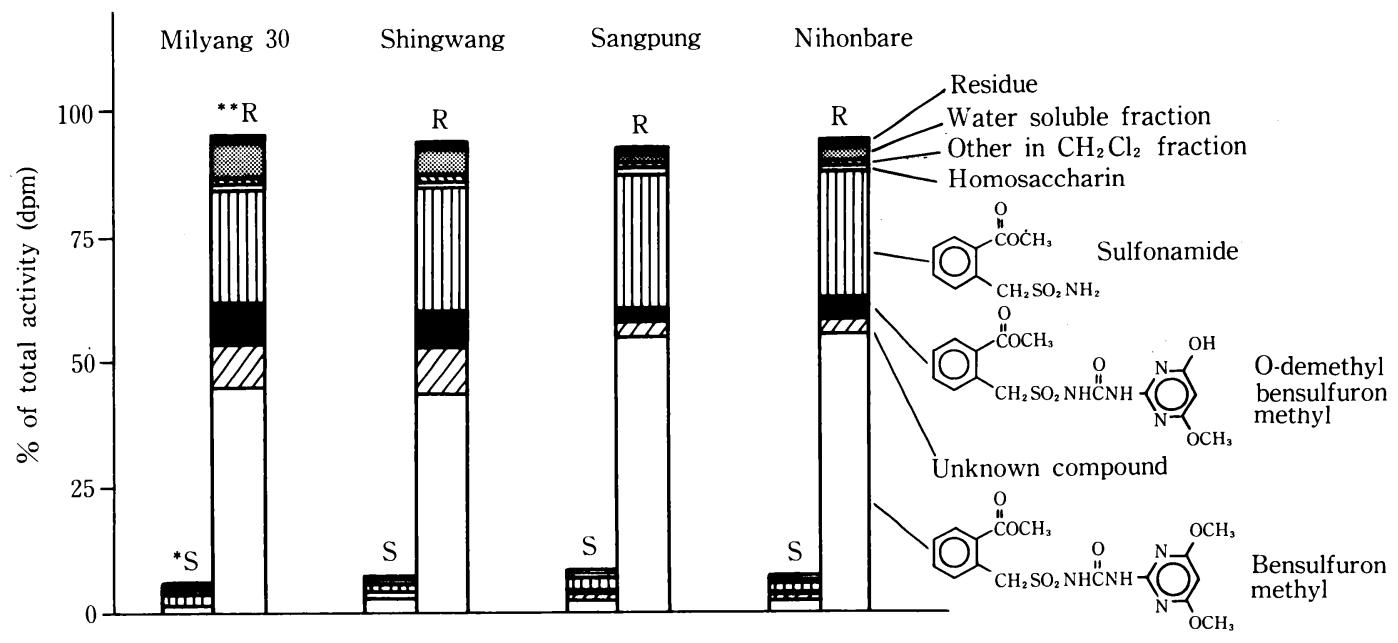

Fig. 3. Distribution of ${ }^{14} \mathrm{C}$-bensulfuron methyl in each fraction of roots and shoots at the 3rd leaf stage of rice plants after 6 hours of exposure and details of the $\mathrm{CH}_{2} \mathrm{Cl}_{2}$ fraction analyzed by TLC. $* \mathrm{~S}$ : shoots ** $\mathrm{R}$ : roots 


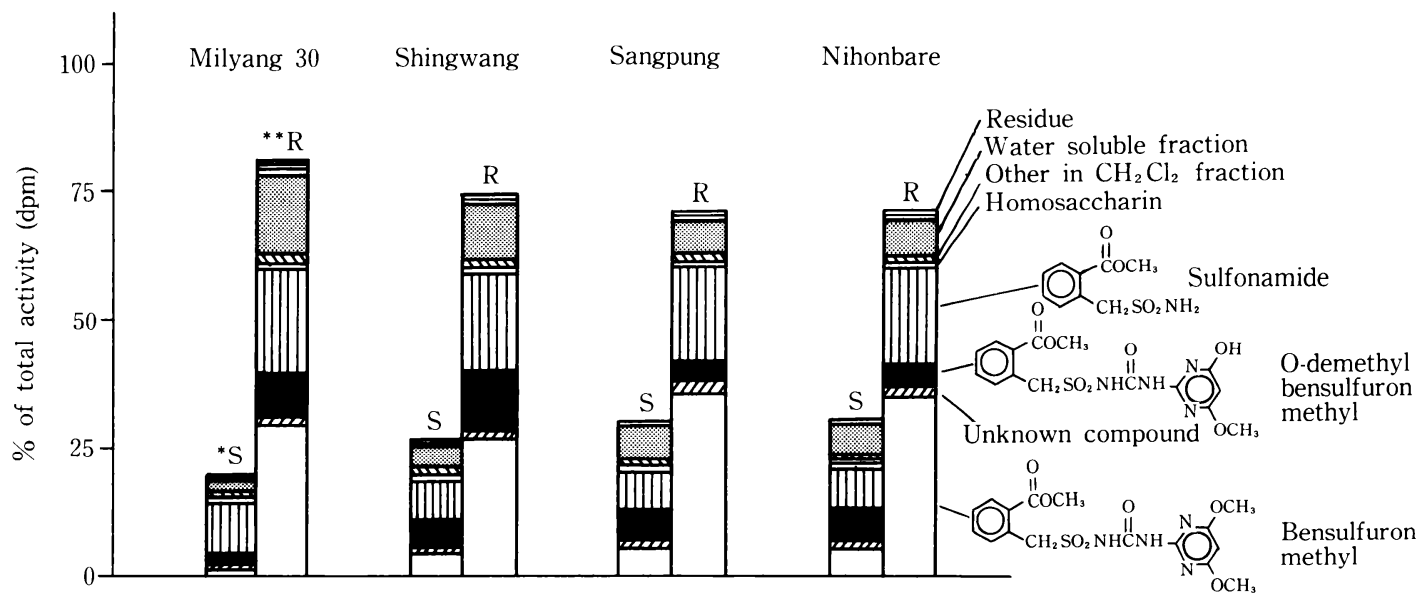

Fig. 4. Distribution of ${ }^{14} \mathrm{C}$-bensulfuron methyl in each fraction of roots and shoots at the 3 rd leaf stage of rice plants after 24 hours of exposure and details of the $\mathrm{CH}_{2} \mathrm{Cl}_{2}$ fraction analyzed by TLC. * $\mathrm{S}$ : shoots $\quad * * \mathrm{R}$ : roots

were larger than in Milyang 30 and Shingwang, a different tendency than seen in roots, while percents of homosaccharin in Milyang 30 and Shingwang were larger than in Sangpung and Nihonbare.

\section{Discussion}

Bensulfuron methyl was applied to roots of rice plants at the 3rd leaf stage. At this time, the 4th leaves were already developed, and the 5 th leaves were just prior to emergence. Differential sensitivity among rice cultivars was investigated in the growth inhibition of the 5th leaf and roots which were directly exposed to the herbicide. The growth and development of the 6th leaf was only in Milyang 30. Considering the effects on growth of the plant parts which grew largely after the application of the hericide. Milyang 30 showed the least degree of inhibition in both shoots and roots (thus a resistant cultivar), while the largest inhibition degree was showed in Nihonbare (a susceptible cultivar). Considering the sensitivity among cultivars treated in shoots (the 4th, 5 th, 6th leaf length and dry weight of shoots) and in roots (dry weight of roots), order of the sensitivity in shoots was Nihonbare $\rangle=\mathrm{Sa}$ ngpung $\rangle=$ Shinseonchalbyeo $\rangle=$ Shingwang $\rangle\rangle$ Milyang 30, and order of the sensitvity in roots was Nihonbare $>=$ Shinseonchalbyeo $>=$ Sangpung $>$ Shingwang $>$ Milyang 30. Putting togeher the results of the growth test, it is concluded that sensitivity to bensulfuron methyl among the rice cultivars is in the order of Nihonbare >Sangpung, Shinseonchalbyeo $>$ Shingwang $\gg>$ Milyang 30 .

Nihonbare, the most sensitive cultivar, showed lower absorption value than other cultivars at 6 hour exposure time, while at 48 hours its value was higher than others. Milyang 30 and Shingwang, resistant cultivars, also showed large absorption value. In $10^{-5} \mathrm{M}$ concetration, the Nihonbare value was lower at 6 hours, while at 48 hours it had a value second only to Shingwang. Milyang 30, the most resistant cultivar, on the other hand, showed the lowest absorption value.

Consequently, there was no distinct relationship between degrees of sensitivity and rates of absorption because the tendencies of absorption in $10^{-6} \mathrm{M}$ and $10^{-5} \mathrm{M}$ differed among the treated cultivars.

Milyang 30 showed lower translocation 
rate than other cultivars and this was correlative with less sensitivity of the shoots. Translocation rates of other cultivars, however, did not correlate with shoot sensitivity.

Milyang 30 and Shingwang had a lower rate of the parent compound in roots than Sangpung and Nihonbare at 6 hour and 24 hour exposure times. In addition, Milyang 30 and Shingwang had a higher rate of O-demethyl bensulfuron methyl and water soluble metabolites than did Sangpung and Nihonbare. These results correlated with the inhibition degree of dry weight of roots. In shoots, Milyang 30 showed a lower rate of the parent compound than the other three rice cultivars at both 6 and 24 hour exposure times. Rate of the parent compound in shoots did not greatly differ among Shingwang, Sangpung and Nihonbare.

On the basis of the growth inhibition in plant parts developing after application of the herbicide, and on the roots which were directly exposed to the herbicide, it is concluded that Milyang 30 followed by Shingwang is the most resistant and Nihonbare the most susceptible among the cultivars tested. In Nihonbare relatively large amounts of the parent compound were detected in both shoots and roots. In Milyang 30, bensuIfuron methyl was less translocated from roots to shoots and largely degraded in roots, and these may contribute to its resistance. The low sensitivity of Shingwang may be related to its high degradation ability in roots. In both cases. high production of $\mathrm{O}$ demethylbensulfuron methyl and water soluble compounds were detected.

Acknowledgements ; The authors express their appreciation to Du Pont de Nemours \& Company for providing ${ }^{14} \mathrm{C}$-labelled bensulfuron methyl and to Prof. Ja Oak Guh and Prof. Young Man Lee of Chonnam National University, Korea, for providing the seeds of several rice cultivars and fruitful suggestions.

\section{References}

1) Ichizen, N. 1976. Varietal difference in the tolerance of rice plants to benthiocarb and simetryn. Weed Res., Japan 21, 80-83 (in Japanese).

2) Kakumoto, Y., H. Matsumoto and K. Ishizuka 1981. Selective mode of action of $s$ triazine herbicides V. Simetryn and dimethametryn among rice cultivars. Weed Res., Japan 26 (Suppl.) 31-32 (in Japanese).

3) Lee, S. and M. Miyahara 1977. Response of indica $\times$ japonica hybrid rice cultivars to simetryn and dimethametryn. Weed Res., Japan 22 (Suppl.) 129-131 (in Japanese).

4) Nakayama, H., W.S. Yang, Y. Takeuchi, M. Konnai and T. Takematsu 1985. Varietal difference in the tolerance of rice cultivars to butachlor and pretilachlor. Proc. Annual Meeting of the Society for Chemical Regulation of Plants. 84-85 (in Japanese).

5) Nakayama, H., Y. Takeuchi, M. Konnai and T. Takematsu 1986. Difference in susceptibility of rice cultivars to DPX-F5384. Weed Res., Japan 31 (Suppl.) 107-108 (in Japanese).

6) Ohno, A., K. Ishizuka, T. Yuyama and S. Takeda 1986. Action and absorption of DPX-F5384 among rice cultivars. Weed Res., Japan 31 (Suppl.) 109-110 (in Japanese).

7) Ray, T.B. 1982. The mode of action of chlorsulfuron-A new herbicide for cereals. Pestic. Biochem. Physiol. 17, 10-17.

8) Ray, T.B. 1984. Site of action of chlorsulfuron-Inhibition of valine and isoleucine biosynthesis in plants. Plant Physiol. 75, 827 -831 .

9) Takeda, S., T. Yuyama, R.C. Ackerson, R.G. Weigel, R.F. Sauers, W. Neal, D.G. Gibian and P.K. Tseng 1985. Herbicidal activities and selectivity of a new rice herbicide DPXF5384. Weed Res., Japan 30, 284-289.

10) Takeda, S., D.L. Erbes, P.B. Sweetser, J.V. Hay and T. Yuyama 1986. Mode of herbicidal and selective action of DPX-F5384 between rice and weeds. Weed Res., Japan 31, 157-163.

11) Yuyama. T., S. Takeda, H. Watanabe, T. Asami, S. Peudpaichit, J.L. Malassa and P. Heiss 1983. DPX-F5384-A new broad spectrum rice herbicide. Proc. 9th Asian-Pacific Weed Sci. Soc. Conf. (Suppl.) 554-559. 


\section{根部施用ベンスルフロンメチルのイネ品種に おける吸収, 移行および代謝}

大野 哲・市 鍾英*・石塚皓造・松本 宏

\section{摘 要}

スルフォニルウレア系の水稲用除草剤ベンスルフロ ンメチルは, イネ品種間に感受性差異のあることが知 られており, その原因がイネに内在する性質によると示 唆されている。本報は, 韓国で行なわれた広範なイネ 品種の選抜試験で特徵的な反応を示した, Milyang 30, Shingwang, Sangpung, Shinseonchalbyeo $の 4$ 品種と, 日本晴品種を用いてベンスルフロンメチルに対する感 受性, 吸収, 移行および分解代謝について, 水耕法に よる根部処理により，比較検討を行なった。

生育試験は，まずイネ根部を $10^{-6}, 5 \times 10^{-6}$ および $10^{-5} \mathrm{M}$ の薬液を含む水耕液に 4 日間浸漬した。その後 薬液を含まない水耕液に移し,さらに 6 日間生育させ た。処理開始から10日目に茎葉, 根部の乾燥重と, 4 葉, 5 葉および 6 葉の長さを測定した。薬剤処理後に 大きく成長して行く部分に着目してベンスルフロンメ チルに対する品種間の感受性差異をみると, 日本晴〉 Sangpung $\rangle=$ Shinseonchalbyeo $>$ Shingwang $\rangle>$ Milyang 30 の順に感受性が高かった (第 1 表)。次に ${ }^{14} \mathrm{C}$-ベン スルフロンメチルを用いて吸収力と根部から茎葉部へ

筑波大学応用生物化学系, *韓国 忠南大学農学部 キーワード：ベンスルフロン・メチル, イネ品種, 吸収, 移 行, 代謝

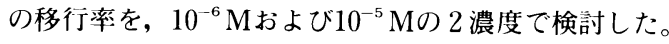
最も感受性の高かった日本晴は，2濃度とも吸収 6 時間では他品種に比べ低い值を示し，48 時間では高 い值を示した。一方，感受性の低かった Shingwang, Milyang 30 は, $10^{-6} \mathrm{M} て ゙ は$ 供試品種中で高い值を示

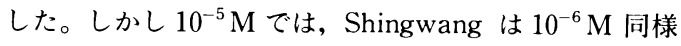
高い值を示したのに対し, Milyang 30 は低い值を示 した (第 1 図)。移行率では, Milyang 30 は $10^{-6} \mathrm{M}$, $10^{-5} \mathrm{M}$ とも他品種に比べ低い值を示したが, Milyang 30 に次いで感受性の低かった Shingwang は $10^{-6} \mathrm{M} て ゙$

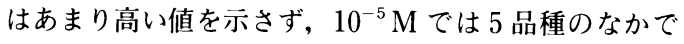
高い值を示した。また日本晴は Shingwang とは逆の関 係を示した (第 2 図)。以上のことにより, 吸収力, 移 行率ともに感受性の品種間差異を説明する大きな要素

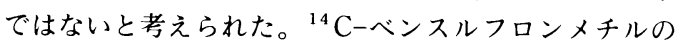
代謝実験は, Shinseonchalbyeo を除いた 4 品種につい て行なった。根部を $10^{-6} \mathrm{M}$ の水溶液に 6 時間および 24 時間浸漬し，植物体中の ${ }^{14} \mathrm{C}$-化合物を抽出，分離，同 定した。その結果, 感受性の低かった品種では, 根部 において O-脱メチルベンスルフロンメチルおよび水溶 性物質の生成の大きいことが明らかとなった（第 3 , 4 図)。

以上, 生育試験におけるベンスルフロンメチルに対 するイネ品種の感受性差異を, 薬剤の吸収, 移行およ び分解代謝から考察すると, 最も感受性の低かった Milyang 30 では, その感受性の低い原因として根部か ら茎葉部への移行率が小さかったこと, および根部で の分解能が他品種に比べ大きかったことが考えられた。 また, Milyang 30 に次いで感受性の低かった Shingwang では, その原因として根部での分解能の大きいこ とが考えられた。 